\title{
Bullying in schools: An interdisciplinary approach from the legal and psycho-pedagogical perspective
}

\section{Tudoriţa GRĂDINARIU•}

\begin{abstract}
The purpose of this study is to analyze bullying behaviors from an interdisciplinary perspective: legal, psychological and pedagogical. From a legal point of view, the Romanian legislative framework on respect for children's rights has undergone a number of changes in recent years with the accession of Romania to the European Union in 2007. International legislation on respect for children's rights requirescountries that have ratified these provisions to ensure that they are respected and to take measures to ensure that they are not prejudiced. Aggressiveness in students is a predictor of antisocial behaviors in adolescence and adulthood.

The psychological perspective of bullying refers to the consequences of this type of behavior.Students involved in aggression are at increased risk of developing a range of psychosomatic symptoms, involvement in delinquency, alcohol and drug abuse, absenteeism. The consequences of these behaviors on the victims are associated with anxiety, depression and suicidal ideation.

Through the pedagogical approach to bullying, we focus on the role of teachers in addressing the issue of aggressive behavior in students. The perceived gravity and teacher's response to bullies and victims of bullying are important indicators to be taken into account in making a successful intervention.
\end{abstract}

Keywords: bullying; bully; victim; child rights; teacher response.

\section{Introduction}

In Romania, 2016 marks the beginning of national studies on the bullying phenomenon in schools.A image of the frequency of this phenomenon in schools is provided by the National Institute of Public Health (INSP) within the National Report on the Health of Children and Young People from Romaniaas a result of a national survey conducted to assess the frequency of some forms of harassment (social isolation, direct and indirect physical and verbal bullying and threat). The results show that $17.9 \%$ of the questioned

\footnotetext{
- PhD student, Faculty of Psychology and Educational Sciences, University Alexandru Ioan Cuza, Iasi, România, tudorita gradinariu@yahoo.com
} 
students were bullied by their peers, and the most common forms of bullying are direct physical and verbal.

Also, this study shows that boys who are aggressive in the primary school have an increased risk of juvenile delinquency and substance abuse. Another important aspect presented in this study is that early aggression is a predictor of antisocial behavior in early adolescence such asmissingschooland scramble with other children (INSP 2016, p. 70).

The literature from this fieldshows that bullying is an international phenomenon that affects children and adolescents all over the world. No culture and no country is immune to the problem of aggression(Stockdale et al., 2002). Bullying behavior is a complex form of interpersonal aggression and is manifested in different patterns of relationship (Swearer\&Hymel, 2015).

According to the Report byNational Center for Education Statistics, U.S. Department of Education, and Bureau of Justice Statistics, Office of Justice Programs, U.S. Department of Justice, Washington, DC, in the 2009-2010 school year, 85\% of public schools experienced one or more incidents of crime of a total of about 1.9 million crimes.Specialists have estimated a rate of 40 offenses per 1000 public schools.In the same year, $60 \%$ of public schools reported at policean offense that occurred in school, respectively 15 offenses per 1,000 pupils in public schools(Robers, Kemp, Rathbun \& Morgan, 2014).

In Romania, over the past two decades, there has been an alarming increase in the number of criminal offenses committed by infants (Kurkó-Fabian, 2006, p.10).According to the statistics of the Superior Council of Magistracy in Romania, over 20,000 juveniles were sued in 2011-2015, of which 15,000 were convicted.Major offenses committed by minors include robbery, hitting, simple or serious bodily injury (Danilet, 2016).

In 2014, the New Penal Code, which regulates the criminal liability of juvenile offenders, invokes the importance of non-custodial educational measures for juvenile offenders. Thus, in 2014-2015, about 800 children were sentenced to detention measures ( Danileț, 2016).

According to the statistical data presented in the Activity Assessment carried out by the Police Inspectorateof Iași in 2014, compared to 2013, a total of 98 crimes were recorded in 2013, out of which 94 were committed in schools, and 4 in areasacrossschool. According 
to the same document, 73 offenses were recorded in 2014, of which 66 were committed in schools, and 7 in the area acrossto the school. In the year 2016, there were 72 offenses, of which 69 in schools, and 3 acrossschools. These data show that school is the place where most offenses are committed by underage children. In addition to these serious behaviors among minors, it adds those that escape a legal investigation and which, through the frequency and complexity of the manifestations, seriously affects the school climate in which students have to study and develop.According to Debarbieux's statements (1996, p. 69), school is not just the placein which crimes are committed, but also the placeof "incivilities" that should not be underestimated.

\section{Definition of bullying}

The concept of "bullying" was introduced for the first time in 1978 by Norwegian psychologist Dan Olweus as a result of school surveys on violent behavior among students (De La Rosa, 2013).Arseneaultand collaborators (2010) statedthat bullying can be defined as a deliberate, malicious form of proactive aggression. It is different from other types of violent behaviors that occur between individuals of similar age, it is repetitive and is characterized by an imbalance of the real or perceived power in which the victim is defenseless.Summarizing the results of allstudies conducted in schools in Scandinavia, Olweus concludes that bullying is a subtype of violent behavior (Olweus, 1997).In the bullying behavior the victim has difficulties in defending herself (Olweus, 1995, p. 197); bullying can be done by a single individual aggressor or by a group the victim may be an individual or a group(Olweus, 1994); bullying is an interaction in which a dominant individual (the bully) repeatedly displays aggressive behavior with the intention of causing harm to a less dominant individual (the victim) (Olweus, 1991; Smith\& Thompson, 1991). 


\section{The bullying behavior from the legal perspective}

A number of international documents refer to human rights and fundamental freedoms as well as to the rights of the child. Countries that have ratified these provisions have an obligation to ensure that they are complied with and to take measures to ensure that they are not prejudiced.

The Universal Declaration of Human Rights adopted by the General Assembly of the United Nations on September 10,1948, proclaims the recognition of human dignity and equal and inalienable rights as the foundation of freedom, justice and peace in the world.It also highlights the importance of education that "must promote understanding, tolerance, friendship among all people and all racial or religious groups ..." ( article 26).

The UN Convention on the Rights of the Child Convention on the Rights of the Child adopted and opened for signature, ratification and accession by General Assembly resolution 44/25 of 20 November 1989recognizes a number of fundamental rights such as the right to life, the right to education, the right to free expression, the right to protection against all forms of violence, injury or abuse, physical or mental, abandonment or neglect, treatments or exploitation.

The Treaty of Lisbonamending the Treaty on European Union and the Treaty establishing the European Community adopted in 1 December 2009regulates the the basic values of social functioning: respect for human dignity, freedom, democracy, equality, compliance with the law, respect for human rights in a society characterized by pluralism, tolerance and non-discrimination.The Romanian legislative framework in the field of children rights protection has supported in recent years a series of modifications and additions as Romania joined the EuropeanUnionin 2007. By adjusting the Romanian legislation to the European one, the status of the child in family and society is reconsidered.

The Constitution Of Romania (1991)guarantees a specialconditionsfor the protection and assistance of children and young people in the realization of their rights (article 49) and in the protection of health of article 34 paragraph 2).

For the first time in Romania, the legislationdefines the child's best interest in law no. 272 of 21 June 2004 on the protection and promotion of the rights of the child.The art. No 
2paragraphNo 1 defines the best interest of the child that includes the child's right to normal physical and moral development, to socio-affective balance and to family life.

Law No. 1 of 5 January 2011 of National Education (The Romanian Parliament,2011) states the indispensable factorsneededin the process of the individual development: "the free, integral and harmonious development of human individuality, thedevelopmentof the autonomous personality and the assumption of a system of values that are necessary for personal fulfillment and development".(The Romanian Parliament, 2011, art.2, alin.3). From the perspective of this law, the purposeof education is represented by the competencesdevelopmentneeded forpersonal fulfillment and growing, social integration and social pro-active beliefs, education in the spirit of dignity, tolerance and respect forhuman rights and fundamental freedoms; cultivation of sensitivity to human issues, to moral-civic values, respect for nature andforthe natural, social and cultural environment " (The Romanian Parliament, 2011, art. 4).

The New Penale Code of Romaniaadopted in 2014(The Romanian Parliament,2009, has undergone a series of transformation, the main changes being those relating to the criminal liability of juvenile offenders. The new perspective of the Penale Code emphasizes first of all the educational component by including sanctions that are designed to correct the infant's behavior in the setting in which he or she lives and develops (house, school) for the case of non-custodial educational measures, or in educational detention centers in the case of educational deprivation of freedom. In Romania, the age for which an infantis legally charged for his acts is 14 .

Law no. 61/1991 Republished for sanctioning the facts of violation of norms of social coexistence, of public order and tranquility,(The Romanian Parliament, 2014)describes antisocial behavior as having a low degree of socialdamage.Thus, at art. 2, par. 1, the antisocial behaviors mentioned as being contraventional charged are: obscene, insulting or vulgar expressions, acts or gestures, violence acts against people or their personal objects the disturbance of the order and the public silence; or damaging their dignity and honor or the ones of the public institutions. " 


\section{The bullying behaviour from the psychological perspective-Consequences of}

\section{bullying behaviors}

Bullying has lifelong negative consequences for everyone implied (bullies, victims and bystanders) and affects in a serious way many aspects of children's livesthat are involved in this type of behavior (Guilory, 2013). Students involved in bullying are at an increased risk of developing a lot of psychosomatic symptoms, being exposed to risks such as leaving home, alcohol and drug abuse, absenteeism, and self-harm. The effects of bullying also extend to adulthood, with research revealing a significant correlation between the aggressive behavior of the child and subsequent psychiatric morbidity(World Health Organisation, 2010).

Victimization is closely linked to the decrease in self-esteem and high rates of depression and anxiety, amongst the victims of bullying, an also a growing occurrence of suicidal thoughts (Losey 2009 apud Limber et al., 2004).

Bullying has an impact on children in adolescence and continues to affect them in adulthood (Espelage \& Swearer, 2004). There is an increase in the interest of specialists in the long-term impact of bullying in order to provide an insight into the urgency in preventing and understanding this phenomenon.

\section{The bullying behaviour from the pedagogical perspective}

Most of the researches areconcerned on the bullying actors and little attention is paid to their teachers and their reactions to the aggressive behavior of students(Yoon\&Kerber, 2003). Although teachers play an important role in the school's safety, little is known about their attitudes towards addressing issues such as bullying (Duong \&Bradshaw, 2013).

Teachers' reactions to aggression can influence the future behaviors of both victims and offenders(Yoon\&Kerber, 2003).The lack of teachers' reaction to school bullying sent unconscious to students the idea that this behavior is accepted and tolerated (Olweus, 1993; Yoon \&Kerber, 2003)

The perceived severity of aggression is a significant factor for the probability of intervention in bullying. There is a possibility that many teachers may not know the extent 
of the verbal and relational aggressions and the damages they cause to the victims (Howard et al., 2001).

A significant number of teachers do not regard social exclusion as aggression, and ignoring this type of aggression can be interpreted by students as being tolerated and permissible (Yoon \& Kerber, 2003). The same authors argue that changing teachers' perceptions and attitudes towards aggressors and victims of social exclusion depends on the degree of knowledge of the social and psychological damage. A positive feedback from teachers will encourage students to report incidents of aggression, while a lack of reaction may result in students the desire torevenge or to ignore the aggression (Small, NeilsenHewett\& Sweller, 2013).

A prevention program should generally try to raise teachers' awareness of aggression, to develop policies that outline the consequences of intimidation, and provide training and support in the field of qualifications for both victims and bullies.

\section{Conclusions}

Olweus was the first researcher to focus on the issue of bullying and has provided important studies and research over the years and has raised the interest of scientists from different countries and continents for this phenomenon (Sanders\&Phye, 2004).The international research has taken up this subject for the purpose of understanding its nature and size, and then to be able tobring solutions to this social problem (Carra, Hedibel, 2009, p. 98).

Over the last four decades, specialists have conducted various studies to guide the prevention of this problem and to stop the violence among students.However, aggression is present in the school settings, and many children suffer quietly every day. The results of the studies show that bullying in school is a "gateway" behavior towards future criminal behavior (Carter, 2012).

Studies show that most teachers are not aware of classroom aggression, which explains the discrepancy between perceived teachers' intervention and effective intervention (Craig \& Pepler, 1997 apud Small, Neilsen-Hewett \& Sweller, 2013).On the 
other hand, Veiga (2001) shows that students who know their rights are better able to defend themselves.

The Romanian criminologist Florian believes that a solution to crime prevention is to take in the consideration of human rights, individual freedoms and responsibilities, and the protection of infants.At the same time, the author presents the necessity of conceiving longterm prevention programs "where specialists intervene based on a scientifically approach" (Florian, 2005, p.4).

In agreement with Florian (2015), we support the importance of an interdisciplinary approach to preventing juvenile delinquency and victimization of infants in which specialists work together for the same purpose.At the same time, like Milsom and Gallo (2006), we consider that an effective program to prevent aggression among students should also refer to the teacher's training from the perspective of recognition and awareness of aggression, the consequences of this problem on the student's health and the possibility of counseling.Additionally, teachers need to be aware of their legal role, namely to be an active participant in respecting children's rights and how to protect them from any form of physical or psychological abuse, abandonment or negligence, unappropiate treatment or exploitation (The UN Convention on the Rights of the Child, 1989).

We conclude that a teacher training program should also refer to the international and national legislative framework alongside of awarenessactionson the severity of bullying and the recognition of the students aggressive types of behaviors.

\section{References:}

Arseneault, L., Bowes, L., \& Shakoor, S. (2010), Bullying victimization in youths and mental health problems: 'Much ado about nothing'?, Psychological Medicine, 40(5), 717-729.

Carra,C.,\& Hedibel, M., E., (2009), Violences in schoosl: European Trends in Research, International Journal of Violence and School, 10, 3-34.

Carter,S., (2012), The bully at school: an interdisciplinary approach, Issues in Comprehensive Pediatric Nursing 35(3-4):153-62 DOI: 10.3109/01460862.2012.708215, Retrieved from https:// www.researchgate.net publication

L233392640_The_Bully_at_School_An_Interdisciplinary_Approach in May, 11, 2018.

Cocorada, E., (2008). Violența școară-perspective teoretice. în E. Cocorada, Evaluare și microviolenţă în mediul scolar (p. 7-28).

Danileț, C., (2016), Analize, Justiție/Ordine Publică, Retreived from http://www.contributors.ro/ administratie/justitieordine-publica/statistici-2011-2015-ep-1-delincventa-juvenila in May, $13,2018$. 
Debarbieux, E., (1996).La violence en milieu scolaire. vol. I, Etat des lieux, ESF, Paris.

Duong, J., Bradshaw, C.P. (2013). Using the Extended Parallel Process Model to Examine Teachers Likelihood of Intervening in Bullying. Journal of School Health, 83, 422-429, Retrieved from https://eric.ed.gov/?q $=$ Using+the+extended+parallel+process +model+to+examine+teachers $\% 27+$ likelihood + of + intervenin g+in+bullying\&id = EJ1011546, in January, 15, 2018.

Espelage, D.L. Swearer, S.M. (2004), Bullying in American schools, Mahwah, NJ:Lawrence Erlbaum Associates.

Evaluarea Activităţilor Desfăşurate de Inspectoratul de Poliție Județean Iaşi în cursul anului 2014 comparativ cu anul 2013, $\quad$ Retreived from https://is.politiaromana.ro/files/pages files/Bilant_IP__asi 2014.pdf, in May, 10, 2018.

Evaluarea Activităţilor Desfăşurate de Inspectoratul de Poliție Județean Iaşi în anul 2016, retreived from https://is.politiaromana.ro/files/pages files/Bilant IPJ Iasi 2016.pdf in May, 13, 2018.

Florian, G. (2005). Prevenirea criminalităţii. Teorie şi practică. București, Ed.Oscar Print;

Guillory, L.A. (2013). An Exploratory Study of Students and Teachers Attitudes Toward Three Types of Bullying: Physical, Verbal and Social Exclusion. University of Massachusetts. Dissertations. p. 742.

Howard, N. M., Horne, A. M., Jolliff, D. (2001). Self-Efficacy in a new training model for the prevention of bullying in schools. In R. A. Geffner, M. Loring, \& C. Young (Eds.), Bullying behavior: Current issues, research, and interventions. NY: The Haworth Press.

Institutul Național de Sănătate Publică din România. (2016). Raportul Național de Sănătate a Copiilor și Tinerilor din România. Retrieved from http://insp.gov.ro/ sites/cnepss/wpcontent/uploads/2017/03/Raport-scolara-2016.pdf in November, 11, 2017.

Kurko Fabian, A. (2006).Delincvenţa juvenilă în România după 1989. Editura Studia, Cluj Napoca.

La Rosa, D., Marie, C. (2013).Differing Perspectives of Bullying between Teachers and Students in Oklahoma Schools, Oklahoma State University, Doctoral Thesis, Retreived from http://www.proquest.com, in December, 20, 2016.

Limber, S., Mullin-Rindler, N., Riese, J., Flerx, V., Snyder, M. (2004). The Olweus bullying prevention program coordinating committee training. Olweus bullying prevention group. Clemson University

Losey, A.,R., (2009), An Evaluation of the Olweus Bullying Prevention Program's Effectiveness in a High School Setting, B.S University of Cincinnati, , Doctoral Thesis.

Milsom, A., Gallo, L.L. (2006). Bullying in middle schools: Prevention and Intervention. Middle School Journal, 37(3), 12-19.

Olweus, D. (1991). Bully/victim problems among school children: Basic facts and effects of a school based intervention program. In I. Rubin \& D. Pepler (Eds.). The development and treatment of childhood aggression (pp. 411-447). Hillsdale, NJ: Erlbaum.

Olweus, D. (1993).Bullying at School: what we know and what we can do. Oxford, Blackwell.

Olweus, D. (1994). Annotation: Bullying at school: Basic facts and effects of a school based intervention program.The Journal of Child Psychology and Psychiatry, 35(7), 1171-1190.

Olweus, D., (1995). Bullying or Peer Abuse at School: Facts and Intervention. Academic Journal, vol. 4 Issue 6, p.196-200.

Olweus, D. (1997). Bully/victims problems in school. Facts and intervention. European Journal of Psychology of Education, Vol. XII, nr.4, p. 495-510.

Robers, S., Kemp, J., Rathbun, A., Morgan, R.E. (2014). Indicators of School Crime and Safety: 2013 (NCES 2014042/NCJ 243299). National Center for Education Statistics, U.S. Department of Education, and Bureau of Justice Statistics, Office of Justice Programs, U.S. Department of Justice. Washington, DC.

Sanders, C.,E.,Phye, G.D. (2004). Bullying in the Classroom, Elsevier Academic Press.

Small, P., Neilsen-Hewett. C., Sweller, N. (2013). Individual and Contextual Factors Shaping Teachers' Attitudes and Responses to Bullying among Young Children: Is Education Important? Asia-Pacific Journal of Research In Early Childhood Education 7(3), pp.69-101. 
Smith, P.K., Thompson, D. (1991). Practical Approaches to Bullying, Great Britain: David Foulton.

Swearer, S.M.,Hymel, S. (2015). Understanding the Psychology of Bullying Moving Toward a Social-Ecological Diathesis-Stress Model. American Psychological Association, 70, 4, 344-353.

Stockdale, M. S., Hangaduambo, S., Duys, D., Larson, K., Sarvela, P. D. (2002). Rural Elementary Students', Parents', and Teachers' Perceptions of Bullying. American Journal of Health Behavior, 26, 4, 266-277.

The Constitution Of Romania Published in the Official Gazette of Romania, Part I, no.233 on November 21, 1991 ,

Retrieved from http://www.legislationline.org/documents/id/4383, in April, 14, 2018.

The Romanian Parliament (2011), Law No. 1 of 5 January 2011 of National Education, Retrieved from

http://www.dreptonline.ro/legislatie/legea_educatiei nationale lege 1_2011.php,

in April, 11, 2018.

The Romanian Parliament,(2009), The New Penale Code of Romaniaadopted by Law No 286/2009, Retrieved from

http://www.mpublic.ro/sites/default/files/PDF/NOILE CODURI/ncp.pdf in April, 13, 2018.

The Romanian Parliament, (2014),Law no. 61/1991 Republished for sanctioning the facts of violation of norms of social coexistence, of public order and tranquility, Retrieved from http://legislatie.just.ro/Public/DetaliiDocument/125693, in April, 23, 2018.

The Romanian Parliament, (2014). Law No. 272 of 21 June 2004, Published In: Official Monitoring No. 159 Of March 5, 2014Retrieved from http://www.mmuncii.ro/j33/images/Documente/Legislatie/L2722004-R.pdf, in May, 12, 2018.

The UN Convention on the Rights of the Child Convention on the Rights of the Child adopted and opened for signature, ratification and accession by General Assembly resolution 44/25 of 20 November 1989, Retrieved from http://www.ohchr.org/EN/ProfessionalInterest/Pages/CRC.aspx in April, 10, 2018.

The Universal Declaration of Human Rights (adopted by the General Assembly of the United Nations on September 10, 1948), Retreived from http://legislatie.resurse-pentrudemocratie.org/legea/declaratia-universala-a-drepturilor-omului.php in May, 10, 2018.

The Treaty of Lisbon amending the Treaty on European Union and the Treaty establishing the European Community adopted in 1 December 2009, Retrieved from http://www.europarl.europa.eu/atyourservice/en/ displayFtu.html?ftuId = FTU 1.1.5.html, in May, $14,2018$.

Yoon, J.S, Kerber, K. (2003). Bullying elementary teachers' attitudes and intervention strategies. Research in Education, 69,27-35.

Veiga, F.H., (2001), School Psychology International,Vol. 22(2): 174-189. [0143-0343 (200105)22:2; 174-189; 017974]. 